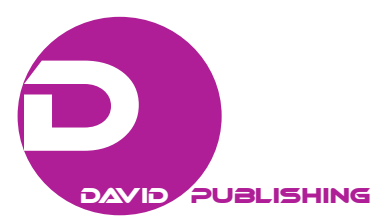

\title{
Family Farms-A New Challenge in the Current World Context
}

\author{
Mihail Dimitriu, Otilia Manta \\ Romanian Academy, Bucharest, Romania
}

\begin{abstract}
The overall goal of European Union and Food and Agriculture Organization of the United Nations is to reposition family farming at the center of agricultural, environmental, and social policies in the national agendas by identifying gaps and opportunities to promote a shift towards a more equal and balanced development. They want to promote directions in order to generate discussion and cooperation at the local, national, regional, and global levels; increase awareness and understanding of the challenges faced by smallholders; and help to identify efficient ways to support family farmers. This paper presents some information on the status and evolution of Romanian agriculture small and medium enterprises (SMEs) and it presents a model for determining the founds needs to support family farmers.
\end{abstract}

Keywords: inclusion, microfinance, economic models, family farms abstract

\section{Introduction}

In Europe, family farmers manage 63 percent of all farmland and guard the agro-biodiversity of soils, water, forests, and fish stocks - resources those future generations will need in order to survive. Despite the differences among the countries in Europe, there are issues that are common to all and this includes the challenges of strengthening sustainable family farming and small-scale production. Romania is part of a growing international movement to recognize the economic, environmental, and cultural value of family farms.

Romania has already taken clear and concrete steps to support its estimated 700,000 smallholders. But there is always more to be done:

- Supporting and invigorating smallholder agriculture requires a comprehensive platform of policy and development initiatives that are tailored to the unique and diverse needs of family farmers.

- To preserve the long-standing tradition of family farming, favourable policy and regulatory environments are needed.

- Improving access to land, water, markets, and credit—as well as standardizing land use and property laws - creates a sound foundation for productivity, solid ground on which farmers can and will invest in the future of their farms.

- Public investment in rural infrastructure, public services, training, and education can give smallholders the help they need to be competitive in an increasingly globalized marketplace.

- Empowering women and young people to participate in agriculture will guarantee the long-term viability

Mihail Dimitriu, Ph.D., Head of Microeconomic Department, Victor Slavescu Centre for Financial and Monetary Research, Romanian Academy, Bucharest, Romania.

Otilia Manta, Ph.D. student, associate researcher, Victor Slavescu Centre for Financial and Monetary Research, Romanian Academy, Bucharest, Romania.

Correspondence concerning this article should be addressed to Otilia Manta, 13 September Street, no. 13, building B, 5th floor, room 5313, Bucharest, Romania. 
of family farming.

The benefits of such a rural development agenda will be evident here in Romania, and today's event will also contribute to making a step forward in this process.

The overall objective of the EU and FAO is to reposition agriculture on the outskirts of agricultural policies, environmental and social national agendas, identifying gaps and opportunities to promote a shift towards a more equal and balanced development. They want to promote the directions to generate discussion and cooperation at local, national, regional, and global levels; raise awareness and understanding of the challenges faced by small farmers; and help to identify effective ways to support family farmers.

Family agriculture includes all agricultural activities family and is related to many areas of rural development. Family agriculture is a means of organizing forestry, fishing, agricultural production, pastoral, and aquaculture, which is managed and operated by a family and work predominantly dependent family, including both women and men. Both in developing countries and developed countries, agriculture is the predominant form of family agriculture in the production of food. Family agriculture is the most common operational model of agriculture in Europe and therefore it is of great importance in the EU. Most of the 12 million EU farms are family farms passed from one generation to another, and contribute to sustainable socio-economic and environmental development of rural areas. There are a variety of family farms in the EU in terms of their size, the activities they engage in, resource availability, the degree of market integration, competitiveness, etc. They operate in different economic contexts, agro-ecological and social ensuring food security while meeting the growing expectations of society for food safety, quality, value, origin and diversity of food, and thus contribute to smart, sustainable, and inclusive. In developing countries, most poor people live in rural areas (Sen, 1999).

Social studies and statistics show that today almost $40 \%$ of rural inhabitants are exposed to ongoing famine. Apart from projections issued by some analysts, specialists in rural areas continue to support the need for a true national development strategy for agriculture, which should have as a starting point in the causes of involution investment process in rural areas and especially those that put farmers unable to accumulate financial resources or access to microcredit/microfinance. Finalizing a strategy for economic development of rural areas must be based on the truth that, under the circumstances, a great chance to ensure food security of the nation lies in restoring production and trade in the area of family farms. In the context of the reality of activities in rural areas, desideratum is a kin to help the development of models of microfinance to respond to these realities and to contribute to the current phenomenon of social inclusion and financial, as well as sustainable development of farms and support non-agricultural activities (Chitea, 2013).

\section{Materials and Methods}

Regarding the methodology of research on microfinance, complexity and diversity of the issues addressed have required the use of methods, techniques, tools, and procedures of scientific investigation and interpretation to which it's attached particular importance:

- Documentation, namely, accessing and studying general and specialized bibliography, domestic and foreign, state approach to knowledge issues investigated rural microfinance and scientific substantiation of the research.

- Rational method, used as an instrument of knowledge, reflection, analysis, organization, and ongoing scientific research approach. 
- Integration of forms, methods, and logic operations research carried out through the use of analysis and synthesis, abstraction and concretization, comparison, generalization, and systematization.

- Statistical methods, through the use of descriptive statistics and statistical analysis.

- Observation method, carried out systematically and analytically.

- Discussions with experts from institutions and national and international institutions, but also the beneficiaries of microfinance products and services.

- Data analysis and interpretation, using graphs, tables, and figures to highlight various developments in microfinance.

Using the classic instruments of scientific research, based on analysis and synthesis, induction and deduction, general and particular, and adding modern methods, authors achieved substantial and pertinent analyses and studies on rural microfinance main ways, both internationally and especially national. Contributions of authors on investigated issue are highlighted during the research work and theoretical and applicative significance value resulting from the conclusions and proposals that they have formulated and promoted.

The research results are presented using tables, figures, and graphs. The theoretical information needed for the research was taken from literature and specialized works in the field of microfinance investigated, from home and abroad. Statistical information and concrete data on how microfinance works were taken from reports and statistics of institutes involved in microfinance in the country and abroad as well as to public bodies and private specialist.

The paper uses software, created specifically for analysis of the business environment in Romania ("Diamond"), which can serve foreign investors who are interested in direct investment capital (establishment of foreign companies in Romania, the acquisition of stakes in domestic companies, etc.) or in cooperation with Romanian companies from various fields of interest. Studies and analyzes are completed at the microeconomic level thereby providing a reality as close as possible to the local business environment. Used data come from the annual accounts of traders in the real economy of Romania in the period 2008-2014 (more than 400,000 balances for each year of the period). Given that the analysis does not use data obtained through questionnaires or surveys, results accurately reflect the economic and financial status (margin of error is minimal and only refers to the processing of data and not the number of operators analyzed). This method of analysis provides a more rigorous substantiation of the decision-making process and also maximum reduction in uncertainty.

\section{Results and Discussions}

Most rural poor depend on agriculture base for most of their meager livelihoods. Others depend on basic non-farm activities such as agro-processing, petty trade, and informal sectors (Herman \& Stefanescu, 2009a). Many of the poor live in rural areas, in regions where arable land is limited, low agricultural potential and environmental degradation are common. Smallholders and family farmers face many challenges (Herman \& Stefanescu, 2009b):

- Climate change and climate variability.

- Lack of tenure security in a context of increasing competition for land and water (population growth, urbanization) and inadequate governance of land tenure.

- Limited access to financial resources, inputs, technology, training, research, advisory services, and education. 
- Price volatility (energy, food, etc.) and limited access to markets.

At the national level, a number of factors there have are a key for successful development of family farming, such as: agro ecological conditions and territorial access to technology and extension services; access to finance; demographic, economic, and socio-cultural conditions; and specialized and availability of education among others.

The goals of the study are to attain better understanding the real financial, social, and economic situation of family farming, and with direct contribution to:

- Economic growth and employment generation towards oriented actions by generating local value added and at the same time ensuring maximum employment options for the local workforce.

- Diversification of the labor force and income generating activities, especially activities by identifying competitive advantages locales — exploit the specialized agriculture, energy, tourism, etc.

- Products (expansion/replacement), markets (sub-products, brands), and processes (cost reduction).

- Business innovation and strengthen actions arising dynamic innovative enterprises at different levels.

- The quality of services, especially education, health, and communications, reflecting the need for adaptation to the challenges of globalization and competitiveness. Emphasis will be only placed on issues of efficiency and accessibility of services.

The study is to be conducted to propose through a series of activities conducted by three partner's organizations, with the assistance of local professional/academic institutions.

\section{Data Collection and Analysis}

Data were collected and analyzes were conducted in the following directions:

- Identification and documentation of family farming policies at national and/or other levels.

- Main organizational bodies that carry out policies.

- Support systems (R\&D, extension services, organizations for access to credit and markets, and support for non-agriculture activities in family farms).

- The best practices in organizations.

- Documentation inside the communities—physical and climate factors, demographic structure agriculture structure, labor force and employment, cultural and social structure, organization, and previous experiences in adoption of innovations.

- The best practices in the community.

- Identification and harnessing of local assets/constrains (economic, social-cultural, demographic, physical, gender, environmental, institutional, and organizational factors).

\section{Formulation and Analysis of Alternative Support and Enterprise Models}

The collected information will be analyzed, highlighting the major constraints and bottlenecks for development and identifying potential advantages and development focal points.

- Identification of technical support options for capacity development actions including policies.

- Identification of non-agricultural activities is complementary with family farming.

- Identification of actors (public-private) is in order to increase their involvement in the support and enterprise models of family and smallholder agriculture in the area.

- The appraisal will include all main assessment factors. 
- Technical (layout, types of technologies, size, scale, types of equipment, location, etc.).

- Institutional (analysis of the implementing and operating agencies regarding their organization and management, examination of the efficiency of utilizing local capabilities and initiatives, and investigation of alternative policy or institutional changes required).

- Economic: an appraisal of the economic costs and benefits of the alternative models, and its impact on the economy and on the welfare of the people who are directly or indirectly affected by it.

- Social: appraisal of social costs and benefits. Special attention will be given to gender, youth, and cultural issues.

- Financial: the model assessment will include formulation of financial analysis that will indicate that there are sufficient funds to cover the costs of implementing it, verifying financial viability.

- Environment: direct or indirect environmental impact.

- Development of human resources and social capita. What is the impact of model on strengthening skills of human capital?

- Sustainability—options that ensure environmental and social sustainability of the projects will be chosen.

- Feasibility: options that are viable from an economic, social, and political view.

- Multiplier effect-options that will enhance the creation of other activities.

Romania joined the EU in 2007, although it has benefited from the financial support of the European institutions, and felt the full impact of the financial crisis since 2008. The situation was even more unfavorable in agriculture, where the predominant activity sized entities small and very small (subsistence farms, small and middle enterprises, etc.).

More reliable information coming from companies was registered as legal entity (annual balance sheets for companies that are registered at the Ministry of Finance as taxpayers). For other entities such as "subsistence farms" are only partly based on information obtained from surveys and questionnaires and only a limited number of units (representative sample).

Based on these considerations, it analyzed the status and progress of SMEs in agriculture in the period of 2008-2014, in terms of the level of production potential, the potential, and the use of economic and financial results.

\section{The Evolution of Indicators Status}

In general, SMEs represent a significant share in the work of Romanian agriculture.

Thus, at the end of 2014, the SMEs group (approximately $90.72 \%$ of the companies working in agriculture) provides approximately $27.61 \%$ of the turnover in agriculture, having about $37.03 \%$ of total assets agriculture and approximately $33.98 \%$ of the total number of employees in agriculture. It is obvious that the main role in agricultural production is the big companies, but provides SME with about two to three employees (average) agriculture "survival".

As can be seen from the data of Table 1, the assets of SME companies (the activity performed in the reporting year) in agriculture increased on average by over 90\% in 2014 compared to 2008, especially in forestry and hunting industries (forestry, logging, and related services, including related service activities hunting).

However, the higher average assets recorded in plant growing and animal breeding basic activities in agriculture in Romania. 
In 2014, SMEs average unit inventories were $57.47 \%$ higher than those of 2008, with the highest values in the livestock sub-branch $(+80.10 \%)$.

The number of employees is one of the most significant indicators of economic potential, which in the period under review remained approximately constant (-7.51\%), standing at a very low level (three employees on average for the SME agriculture!).

As can be seen from the data of Table 1, the number of SMEs in agriculture in the period under review increased by $34.96 \%$ to 16,602 in 2014 . The structure, most SMEs are still in the activities of plant growth and animal husbandry, which together give more than $62.02 \%$ of all SMEs in agriculture.

Table 1

The Number of SME in Agriculture Spread Over Sub-sectors in the Period 2008-2014

\begin{tabular}{|c|c|c|c|c|c|c|c|c|}
\hline \multirow{2}{*}{$\begin{array}{l}\text { Nr. } \\
\text { Crt. }\end{array}$} & \multirow[b]{2}{*}{ Sub-sectors of agriculture } & \multirow{2}{*}{$\begin{array}{l}\text { The number of } \\
\text { microenterpris } \\
\text { es at december } \\
31,2014 \\
\text {-lei- }\end{array}$} & \multicolumn{6}{|c|}{ Dynamics $(2008=100 \%)$} \\
\hline & & & 2009 & 2010 & 2011 & 2012 & 2013 & 2014 \\
\hline 1 & Total Romanian real economy & 457,446 & 109.20 & 103.77 & 104.94 & 104.71 & 109.97 & 109.45 \\
\hline 2 & Total agriculture & 18,299 & 106.00 & 112.98 & 120.97 & 124.83 & 130.56 & 133.07 \\
\hline 3 & Total agriculture (SME) & 16,602 & 109.28 & 115.79 & 122.35 & 127.22 & 132.50 & 134.96 \\
\hline 4 & Plant growing & 6,697 & 106.77 & 112.88 & 119.58 & 125.93 & 131.67 & 135.02 \\
\hline 5 & Animal breeding and veterinary care & 3,599 & 116.07 & 123.44 & 131.06 & 137.26 & 143.63 & 149.83 \\
\hline 6 & Activities in mixed farms and related services & 2,918 & 112.44 & 126.38 & 141.56 & 145.84 & 150.49 & 150.65 \\
\hline 7 & Hunting including related service activities & 52 & 126.83 & 114.63 & 146.34 & 126.83 & 143.90 & 126.83 \\
\hline 8 & Forestry, logging, and related services & 2,820 & 103.24 & 103.28 & 102.97 & 104.69 & 107.51 & 107.51 \\
\hline 9 & Fishing, aquaculture & 516 & 124.26 & 140.53 & 138.46 & 142.90 & 155.03 & 152.66 \\
\hline
\end{tabular}

Source: Calculated using data from the economic and financial situations reported by economic operators from Agriculture, Romanian Ministry of Public Finance (2008-2014).

In terms of the use of economic and financial potential, it is noted that labor costs rose by $50.04 \%$ in the period under review, the average for SMEs in agriculture, although the number of employees remained approximately constant (-6.51\%).

Due to the faster increase in material costs, operating costs increased in the period by $60.36 \%$, mainly in sub-branches basic plant growth and livestock (+64.85\% and 69.79\%). Territorially, the highest increases were registered in the North-East and Bucharest-Ilfov.

From the point of view of economic and financial results, it notes that:

- A significant increase in turnover average in agriculture (+73.03\%) in the period under review, even under ecoomico financial crisis.

- Faster growth in turnover compared with operating profit (+89.95\%), especially in sub-branch hunting (122.45\%), forestry (+122.04\%), and crop (105.55\%).

- A doubling of operating losses in agriculture $(166,205)$, especially in plant growth $(+211.68 \%)$, hunting (+189.87\%) and livestock.

- Increases in SME activity in agriculture in terms of turnover were achieved by increased $88.07 \%$ over the period analyzed the short-term debt and $79.72 \%$ in the medium and long term debt.

In those circumstances, the following problems occur:

- If Romania wants a future based on SME agricultural production? 
If so, then the following questions arise:

- Production mechanism based on debt can be sustainable in the medium and long term?

- In the circumstances, the current mechanism for providing financial resources is viable or should be restructured?

- Stimulating employees to achieve agricultural production is real or only apparent (given that the level of inflation in the period is under review crescutcu 28.70\%)?

Given the data presented, the determination of the annual funding of agricultural production by SME can use formula:

$$
\mathrm{NF}=\mathrm{CT}+\mathrm{DPS}-\mathrm{AC}
$$

where: NF-necessary financing; CT—total cost of ownership; DPS—short-term debt; and AC—current assets.

For example, in 2014, active SMEs (which recorded turnover) of Romanian agriculture, according to data from Table 2 to Table 19, were recorded as follows:

1. Number of companies-16,602.

2. The average total cost of operation per unit-731,308 lei.

3. Accounts payable average unit-623,640 lei.

4. Current assets average unit-605,710 lei.

Thus, borrowing for 2014 would be as: NF = 16,602 $*(731,308+623,640-605,710)=12,438,849,276$ lei, or 749,238 lei on average for SMEs in agriculture.

These results must, however, correlated with the main indicator of "performance" (debt recovery) which is 546 days (averaged for 2014)! So on average output, it needs one and a half years to pay off existing debts only in 2014. However, this situation is getting worse. While agricultural production in SMEs increased in 2014 by 9.23\% compared to the previous year, total debt increased by 13.61\% (2014/2013).

Table 2

The Total Value of Assetes per Unit for Micro-enterprises (SME) in Agriculture Spread Over Sub-sectors of Activity, 2008-2014

\begin{tabular}{|c|c|c|c|c|c|c|c|c|}
\hline \multirow{2}{*}{$\begin{array}{l}\text { Nr. } \\
\text { Crt. }\end{array}$} & \multirow{2}{*}{ Sub-sectors of agriculture } & \multirow{2}{*}{$\begin{array}{l}\text { Total assets } \\
\text { per unit } \\
\text { at december } \\
31,2014 \\
\text {-lei- }\end{array}$} & \multicolumn{6}{|c|}{ Dynamics (2008 = 100\%) } \\
\hline & & & 2009 & 2010 & 2011 & 2012 & 2013 & 2014 \\
\hline 1 & Total Romanian real economy & $2,641,346$ & 90.88 & 105.25 & 112.10 & 111.04 & 111.33 & 114.08 \\
\hline 2 & Total agriculture & $3,352,697$ & 98.66 & 111.88 & 107.48 & 117.45 & 114.74 & 126.40 \\
\hline 3 & Total agriculture (SME) & $1,368,727$ & 115.84 & 130.36 & 155.15 & 167.15 & 169.93 & 193.96 \\
\hline 4 & Plant growing & $1,971,391$ & 111.20 & 122.28 & 145.05 & 159.60 & 166.59 & 193.75 \\
\hline 5 & Animal breeding and veterinary care & 958,637 & 109.38 & 122.32 & 143.83 & 162.40 & 168.17 & 182.38 \\
\hline 6 & Activities in mixed farms and related services & $1,014,535$ & 112.30 & 140.37 & 173.28 & 173.67 & 174.46 & 180.91 \\
\hline 7 & Hunting including related service activities & 911,064 & 186.19 & 141.62 & 191.25 & 197.07 & 171.58 & 300.74 \\
\hline 8 & Forestry, logging, and related services & 878,720 & 161.22 & 169.13 & 200.71 & 190.28 & 170.61 & 216.29 \\
\hline 9 & Fishing, aquaculture & $1,134,261$ & 85.06 & 145.03 & 154.54 & 201.62 & 183.27 & 185.28 \\
\hline
\end{tabular}

Source: Calculated using data from the economic and financial situations reported by economic operators from Agriculture, Romanian Ministry of Public Finance (2008-2014). 
Table 3

The Value of Fixed Assets per Unit for SME in Agriculture Spread Over Sub-sectors of Activity During 2008-2014

\begin{tabular}{|c|c|c|c|c|c|c|c|c|}
\hline \multirow{2}{*}{$\begin{array}{l}\text { Nr. } \\
\text { Crt. }\end{array}$} & \multirow{2}{*}{ Sub-sectors of agriculture } & \multirow{2}{*}{$\begin{array}{l}\text { Assets per unit } \\
\text { at december } \\
31,2014 \\
\text {-lei- }\end{array}$} & \multicolumn{6}{|c|}{ Dynamics (2008 = 100\%) } \\
\hline & & & 2009 & 2010 & 2011 & 2012 & 2013 & 2014 \\
\hline 1 & Total Romanian real economy & $1,461,380$ & 90.89 & 102.68 & 105.08 & 100.31 & 103.49 & 105.40 \\
\hline 2 & Total agriculture & $1,832,641$ & 95.92 & 110.82 & 93.52 & 99.32 & 97.36 & 105.85 \\
\hline 3 & Total agriculture (SME) & 763,017 & 123.51 & 137.83 & 163.43 & 175.60 & 178.86 & 198.12 \\
\hline 4 & Plant growing & $1,054,178$ & 114.33 & 123.31 & 144.26 & 156.63 & 164.80 & 182.31 \\
\hline 5 & Animal breeding and veterinary care & 527,080 & 108.08 & 120.67 & 141.39 & 158.70 & 173.61 & 180.44 \\
\hline 6 & Activities in mixed farms and related services & 581,179 & 115.65 & 156.68 & 178.69 & 191.82 & 192.77 & 193.14 \\
\hline 7 & Hunting including related service activities & 322,230 & 220.77 & 115.41 & 203.56 & 203.36 & 190.18 & 249.39 \\
\hline 8 & Forestry, logging, and related services & 598,515 & 227.65 & 246.55 & 302.93 & 277.71 & 237.61 & 325.22 \\
\hline 9 & Fishing, aquaculture & 601,482 & 87.50 & 97.63 & 170.97 & 252.51 & 210.04 & 209.40 \\
\hline
\end{tabular}

Source: Calculated using data from the economic and financial situations reported by economic operators from Agriculture, Romanian Ministry of Public Finance (2008-2014).

Table 4

The Value of Material Stocks per Unit for SME in Agriculture Spread Over Sub-sectors of Activity During 2008-2014

\begin{tabular}{|c|c|c|c|c|c|c|c|c|}
\hline \multirow{2}{*}{$\begin{array}{l}\text { Nr. } \\
\text { Crt. }\end{array}$} & \multirow[b]{2}{*}{ Sub-sectors of agriculture } & \multirow{2}{*}{$\begin{array}{l}\text { Material stocks } \\
\text { per unit at } \\
\text { december 31, } \\
2014 \\
\text {-lei- } \\
\end{array}$} & \multicolumn{6}{|c|}{ Dynamics $(2008=100 \%)$} \\
\hline & & & 2009 & 2010 & 2011 & 2012 & 2013 & 2014 \\
\hline 1 & Total Romanian real economy & 323,903 & 93.45 & 99.34 & 114.63 & 135.15 & 124.34 & 132.95 \\
\hline 2 & Total agriculture & 538,123 & 85.08 & 97.00 & 106.74 & 112.49 & 108.41 & 111.18 \\
\hline 3 & Total agriculture (SME) & 200,662 & 97.04 & 104.99 & 112.64 & 133.42 & 137.26 & 157.47 \\
\hline 4 & Plant growing & 317,132 & 94.19 & 105.05 & 108.92 & 130.51 & 134.37 & 160.28 \\
\hline 5 & Animal breeding and veterinary care & 155,058 & 108.31 & 117.34 & 126.14 & 158.50 & 155.88 & 180.10 \\
\hline 6 & Activities in mixed farms and related services & 108,867 & 96.00 & 88.09 & 98.08 & 110.50 & 116.48 & 111.40 \\
\hline 7 & Hunting including related service activities & 134,753 & 193.13 & 153.12 & 247.08 & 188.82 & 166.31 & 159.67 \\
\hline 8 & Forestry, logging, and related services & 71,581 & 105.21 & 110.54 & 132.67 & 137.41 & 136.54 & 141.12 \\
\hline 9 & Fishing, aquaculture & 238,311 & 87.15 & 97.74 & 112.16 & 121.70 & 139.83 & 150.38 \\
\hline \multicolumn{9}{|c|}{$\begin{array}{l}\text { Source: Calculated using data from the economic and financial situations reported by economic operators from Agriculture } \\
\text { Romanian Ministry of Public Finance (2008-2014). }\end{array}$} \\
\hline \multicolumn{9}{|c|}{ The Money Availabilities per Unit for SME in Agriculture Spread Over Sub-sectors of Activity During 2008-2014 } \\
\hline \multirow[b]{2}{*}{$\begin{array}{l}\text { Nr. } \\
\text { Crt. }\end{array}$} & \multirow[b]{2}{*}{ Sub-sectors of agriculture } & \multirow{2}{*}{$\begin{array}{l}\text { The money } \\
\text { availabilities } \\
\text { per unit, } \\
\text { december 31, } \\
2014 \\
\text {-lei- }\end{array}$} & \multicolumn{6}{|c|}{ Dynamics $(2008$ = 100\%) } \\
\hline & & & 2009 & 2010 & 2011 & 2012 & 2013 & 2014 \\
\hline 1 & Total Romanian real economy & 175,815 & 87.87 & 99.07 & 104.66 & 102.07 & 106.94 & 122.58 \\
\hline 2 & Total agriculture & 177,204 & 104.58 & 136.04 & 160.05 & 162.59 & 179.92 & 220.56 \\
\hline 3 & Total agriculture (SME) & 88,307 & 107.86 & 131.00 & 158.76 & 157.33 & 167.83 & 208.82 \\
\hline 4 & Plant growing & 123,918 & 128.32 & 169.44 & 191.56 & 191.45 & 214.59 & 259.52 \\
\hline 5 & Animal breeding and veterinary care & 58,432 & 96.98 & 91.41 & 114.43 & 112.06 & 114.18 & 152.18 \\
\hline
\end{tabular}


Table 5 continued

\begin{tabular}{|c|c|c|c|c|c|c|c|c|}
\hline \multirow{2}{*}{$\begin{array}{l}\text { Nr. } \\
\text { Crt. }\end{array}$} & \multirow[b]{2}{*}{ Sub-sectors of agriculture } & \multirow{2}{*}{$\begin{array}{l}\text { The money } \\
\text { availabilities } \\
\text { per unit, } \\
\text { december 31, } \\
2014 \\
\text {-lei- }\end{array}$} & \multicolumn{6}{|c|}{ Dynamics $(2008=100 \%)$} \\
\hline & & & 2009 & 2010 & 2011 & 2012 & 2013 & 2014 \\
\hline 6 & Activities in mixed farms and related services & 65,984 & 119.38 & 146.03 & 203.76 & 158.48 & 156.69 & 200.64 \\
\hline 7 & Hunting including related service activities & 143,196 & 164.71 & 238.12 & 174.19 & 143.26 & 102.33 & 603.43 \\
\hline 8 & Forestry, logging, and related services & 73,452 & 75.70 & 85.32 & 107.47 & 134.78 & 132.99 & 166.76 \\
\hline 9 & Fishing, aquaculture & 36,388 & 51.61 & 64.70 & 102.64 & 104.37 & 115.39 & 112.62 \\
\hline
\end{tabular}

Source: Calculated using data from the economic and financial situations reported by economic operators from Agriculture, Romanian Ministry of Public Finance (2008-2014).

Table 6

Circulating Assets Value per Unit for SME in Agriculture Spread Over Sub-sectors of Activity During 2008-2014

\begin{tabular}{|c|c|c|c|c|c|c|c|c|}
\hline \multirow{2}{*}{$\begin{array}{l}\text { Nr. } \\
\text { Crt. }\end{array}$} & \multirow[b]{2}{*}{ Sub-sectors of agriculture } & \multirow{2}{*}{$\begin{array}{l}\text { Circulating } \\
\text { assets value } \\
\text { per unit at } \\
\text { december 31, } \\
2014 \\
\text {-lei- }\end{array}$} & \multicolumn{6}{|c|}{ Dynamics $(2008=100 \%)$} \\
\hline & & & 2009 & 2010 & 2011 & 2012 & 2013 & 2014 \\
\hline 1 & Total Romanian real economy & $1,179,966$ & 90.87 & 109.09 & 122.57 & 127.07 & 123.04 & 127.07 \\
\hline 2 & Total agriculture & $1,520,056$ & 103.82 & 113.86 & 133.73 & 151.53 & 147.40 & 165.04 \\
\hline 3 & Total agriculture (SME) & 605,710 & 106.62 & 121.39 & 145.21 & 157.00 & 159.19 & 188.96 \\
\hline 4 & Plant growing & 917,213 & 107.07 & 120.93 & 146.10 & 163.50 & 168.93 & 208.80 \\
\hline 5 & Animal breeding and veterinary care & 431,557 & 111.01 & 124.37 & 146.89 & 167.03 & 161.37 & 184.80 \\
\hline 6 & Activities in mixed farms and related services & 433,356 & 108.41 & 121.47 & 167.02 & 152.64 & 153.25 & 166.75 \\
\hline 7 & Hunting including related service activities & 588,834 & 160.47 & 161.11 & 182.10 & 192.39 & 157.75 & 338.93 \\
\hline 8 & Forestry, logging, and related services & 280,205 & 106.21 & 105.03 & 116.06 & 117.88 & 115.13 & 126.08 \\
\hline 9 & Fishing, aquaculture & 532,779 & 82.90 & 186.92 & 140.01 & 156.64 & 159.60 & 163.96 \\
\hline
\end{tabular}

Source: Calculated using data from the economic and financial situations reported by economic operators from Agriculture, Romanian Ministry of Public Finance (2008-2014).

Table 7

The Average Number of Staff per Unit for SME in Agriculture Spread Over Sub-sectors of Activity During 2008-2014

\begin{tabular}{|c|c|c|c|c|c|c|c|c|}
\hline \multirow{2}{*}{$\begin{array}{l}\text { Nr. } \\
\text { Crt. }\end{array}$} & \multirow{2}{*}{ Sub-sectors of agriculture } & \multirow{2}{*}{$\begin{array}{l}\text { The average } \\
\text { number of } \\
\text { staff per unit at } \\
\text { december 31, } \\
2014 \\
\text {-lei- }\end{array}$} & \multicolumn{6}{|c|}{ Dynamics $(2008=100 \%)$} \\
\hline & & & 2009 & 2010 & 2011 & 2012 & 2013 & 2014 \\
\hline 1 & Total Romanian real economy & 8.49 & 88.07 & 84.49 & 87.41 & 85.15 & 81.01 & 79.78 \\
\hline 2 & Total agriculture & 7.29 & 84.16 & 85.67 & 82.74 & 79.82 & 74.65 & 73.54 \\
\hline 3 & Total agriculture (SME) & 2.73 & 230.92 & 153.37 & 110.36 & 96.41 & 95.58 & 93.49 \\
\hline 4 & Plant growing & 2.76 & 90.11 & 232.33 & 93.95 & 92.72 & 91.60 & 91.60 \\
\hline 5 & Animal breeding and veterinary care & 2.38 & 91.26 & 94.47 & 96.54 & 95.68 & 96.22 & 94.24 \\
\hline 6 & Activities in mixed farms and related services & 2.92 & 575.70 & 117.89 & 191.36 & 115.42 & 113.99 & 109.22 \\
\hline 7 & Hunting including related service activities & 2.10 & 90.59 & 80.74 & 98.87 & 93.11 & 82.80 & 91.43 \\
\hline 8 & Forestry, logging, and related services & 2.93 & 403.24 & 96.42 & 97.93 & 94.99 & 94.31 & 91.19 \\
\hline 9 & Fishing, aquaculture & 2.72 & 77.72 & 77.82 & 82.22 & 82.86 & 82.26 & 74.89 \\
\hline
\end{tabular}

Source: Calculated using data from the economic and financial situations reported by economic operators from Agriculture, Romanian Ministry of Public Finance (2008-2014). 
Table 8

The Amortization Expense of Tangible Assets per Unit for SME in Agriculture Distributed by Industry During 2008-2014

\begin{tabular}{|c|c|c|c|c|c|c|c|c|}
\hline \multirow[b]{2}{*}{$\begin{array}{l}\text { Nr. } \\
\text { Crt. }\end{array}$} & \multirow[b]{2}{*}{ Sub-sectors of agriculture } & \multirow{2}{*}{$\begin{array}{l}\text { The } \\
\text { amortization } \\
\text { expense of } \\
\text { tangible assets } \\
\text { per unit at } \\
\text { december 31, } \\
2014 \\
\text {-lei- }\end{array}$} & \multicolumn{6}{|c|}{ Dynamics (2008 = 100\%) } \\
\hline & & & 2009 & 2010 & 2011 & 2012 & 2013 & 2014 \\
\hline 1 & Total Romanian real economy & 111,821 & 99.09 & 112.66 & 125.00 & 114.72 & 120.00 & 126.59 \\
\hline 2 & Total agriculture & 153,893 & 114.99 & 131.44 & 155.03 & 169.25 & 179.03 & 193.29 \\
\hline 3 & Total agriculture (SME) & 63,163 & 123.21 & 145.88 & 181.85 & 206.20 & 222.03 & 237.70 \\
\hline 4 & Plant growing & 96,646 & 128.36 & 157.94 & 187.53 & 215.57 & 233.15 & 257.82 \\
\hline 5 & Animal breeding and veterinary care & 40,416 & 111.87 & 133.40 & 157.25 & 157.57 & 180.94 & 204.76 \\
\hline 6 & Activities in mixed farms and related services & 63,191 & 122.08 & 129.84 & 210.96 & 254.28 & 273.45 & 267.01 \\
\hline 7 & Hunting including related service activities & 19,940 & 374.58 & 174.48 & 245.25 & 138.97 & 192.57 & 220.45 \\
\hline 8 & Forestry, logging, and related services & 19,772 & 126.00 & 139.37 & 140.29 & 138.71 & 137.27 & 126.02 \\
\hline 9 & Fishing, aquaculture & 28,596 & 71.62 & 84.80 & 174.91 & 224.46 & 179.85 & 156.87 \\
\hline
\end{tabular}

Source: Calculated using data from the economic and financial situations reported by economic operators from Agriculture, Romanian Ministry of Public Finance (2008-2014).

Table 9

Labor Costs per Unit for SME in Agriculture Distributed by Industry During 2008-2014

\begin{tabular}{|c|c|c|c|c|c|c|c|c|}
\hline \multirow{2}{*}{$\begin{array}{l}\text { Nr. } \\
\text { Crt. }\end{array}$} & \multirow{2}{*}{ Sub-sectors of agriculture } & \multirow{2}{*}{$\begin{array}{l}\text { Labor costs per } \\
\text { unit at } \\
\text { december 31, } \\
2014 \\
\text {-lei- }\end{array}$} & \multicolumn{6}{|c|}{ Dynamics $(2008=100 \%)$} \\
\hline & & & 2009 & 2010 & 2011 & 2012 & 2013 & 2014 \\
\hline 1 & Total Romanian real economy & 257,557 & 87.15 & 92.06 & 103.23 & 103.93 & 106.60 & 113.57 \\
\hline 2 & Total agriculture & 179,192 & 91.22 & 93.02 & 94.33 & 98.61 & 100.68 & 108.36 \\
\hline 3 & Total agriculture (SME) & 43,358 & 105.87 & 101.80 & 117.90 & 128.32 & 135.64 & 150.04 \\
\hline 4 & Plant growing & 49,004 & 105.21 & 103.25 & 112.87 & 125.29 & 132.80 & 147.99 \\
\hline 5 & Animal breeding and veterinary care & 34,673 & 100.92 & 100.79 & 108.13 & 114.79 & 125.05 & 136.16 \\
\hline 6 & Activities in mixed farms and related services & 48,261 & 108.86 & 99.68 & 140.27 & 157.05 & 165.94 & 188.55 \\
\hline 7 & Hunting including related service activities & 29,694 & 91.22 & 107.97 & 90.00 & 68.38 & 67.88 & 105.22 \\
\hline 8 & Forestry, logging, and related services & 37,281 & 116.77 & 107.45 & 128.21 & 132.41 & 134.53 & 144.41 \\
\hline 9 & Fishing, aquaculture & 37,530 & 79.17 & 76.10 & 93.58 & 98.54 & 105.17 & 109.31 \\
\hline
\end{tabular}

Source: Calculated using data from the economic and financial situations reported by economic operators from Agriculture, Romanian Ministry of Public Finance (2008-2014).

Table 10

Operating Costs per Unit for SME in Agriculture Distributed by Industry During 2008-2014

\begin{tabular}{|c|c|c|c|c|c|c|c|c|}
\hline \multirow{2}{*}{$\begin{array}{l}\text { Nr. } \\
\text { Crt. }\end{array}$} & \multirow{2}{*}{ Sub-sectors of agriculture } & \multirow{2}{*}{$\begin{array}{l}\text { Operating } \\
\text { costs per unit } \\
\text { at december } \\
31,2014 \\
\text {-lei- }\end{array}$} & \multicolumn{6}{|c|}{ Dynamics $(2008=100 \%)$} \\
\hline & & & 2009 & 2010 & 2011 & 2012 & 2013 & 2014 \\
\hline 1 & Total Romanian real economy & $2,434,295$ & 81.19 & 92.83 & 108.17 & 110.04 & 106.59 & 109.63 \\
\hline 2 & Total agriculture & $2,246,683$ & 93.87 & 97.31 & 121.96 & 129.80 & 124.63 & 130.54 \\
\hline 3 & Total agriculture (SME) & 697,187 & 103.19 & 115.09 & 142.44 & 155.06 & 148.63 & 160.36 \\
\hline
\end{tabular}


Table 10 continued

\begin{tabular}{|c|c|c|c|c|c|c|c|c|}
\hline \multirow{2}{*}{$\begin{array}{l}\text { Nr. } \\
\text { Crt. }\end{array}$} & \multirow{2}{*}{ Sub-sectors of agriculture } & \multirow{2}{*}{$\begin{array}{l}\text { Operating } \\
\text { costs per unit } \\
\text { at december } \\
31,2014 \\
\text {-lei- }\end{array}$} & \multicolumn{6}{|c|}{ Dynamics $(2008=100 \%)$} \\
\hline & & & 2009 & 2010 & 2011 & 2012 & 2013 & 2014 \\
\hline 4 & Plant growing & 955,807 & 96.70 & 119.07 & 142.70 & 165.26 & 149.70 & 164.85 \\
\hline 5 & Animal breeding and veterinary care & 627,991 & 112.91 & 116.60 & 148.13 & 143.12 & 160.09 & 169.79 \\
\hline 6 & Activities in mixed farms and related services & 512,218 & 104.79 & 108.59 & 157.90 & 158.24 & 149.39 & 154.80 \\
\hline 7 & Hunting including related service activities & 275,343 & 153.04 & 166.55 & 149.61 & 115.53 & 234.05 & 142.60 \\
\hline 8 & Forestry, logging, and related services & 445,031 & 95.30 & 110.17 & 124.83 & 125.67 & 128.53 & 135.65 \\
\hline 9 & Fishing, aquaculture & 289,865 & 303.14 & 103.72 & 128.25 & 185.55 & 142.36 & 131.87 \\
\hline
\end{tabular}

Source: Calculated using data from the economic and financial situations reported by economic operators from Agriculture, Romanian Ministry of Public Finance (2008-2014).

Table 11

Total Costs per Unit for SME in Agriculture Distributed by Industry During 2008-2014

\begin{tabular}{|c|c|c|c|c|c|c|c|c|}
\hline \multirow{2}{*}{$\begin{array}{l}\text { Nr. } \\
\text { Crt. }\end{array}$} & \multirow{2}{*}{ Sub-sectors of agriculture } & \multirow{2}{*}{$\begin{array}{l}\text { Total costs per } \\
\text { unit at } \\
\text { december 31, } \\
2014 \\
\text {-lei- }\end{array}$} & \multicolumn{6}{|c|}{ Dynamics $(2008=100 \%)$} \\
\hline & & & 2009 & 2010 & 2011 & 2012 & 2013 & 2014 \\
\hline 1 & Total Romanian real economy & $2,512,787$ & 80.62 & 92.83 & 107.68 & 109.11 & 104.91 & 106.93 \\
\hline 2 & Total agriculture & $2,325,645$ & 94.28 & 96.70 & 120.58 & 128.20 & 122.50 & 128.38 \\
\hline 3 & Total agriculture (SME) & 731,308 & 104.91 & 115.24 & 142.90 & 154.58 & 148.25 & 160.52 \\
\hline 4 & Plant growing & $1,012,586$ & 98.01 & 118.98 & 141.65 & 163.81 & 149.79 & 165.85 \\
\hline 5 & Animal breeding and veterinary care & 644,975 & 113.44 & 115.64 & 146.35 & 142.30 & 157.80 & 166.37 \\
\hline 6 & Activities in mixed farms and related services & 544,745 & 104.88 & 108.38 & 162.76 & 157.16 & 147.53 & 155.94 \\
\hline 7 & Hunting including related service activities & 292,924 & 164.23 & 171.89 & 158.75 & 123.09 & 248.46 & 149.97 \\
\hline 8 & Forestry, logging, and related services & 454,076 & 102.32 & 112.89 & 128.62 & 127.68 & 129.30 & 135.20 \\
\hline 9 & Fishing, aquaculture & 297,152 & 289.28 & 100.66 & 126.08 & 189.63 & 138.30 & 127.23 \\
\hline
\end{tabular}

Source: Calculated using data from the economic and financial situations reported by economic operators from Agriculture, Romanian Ministry of Public Finance (2008-2014).

Table 12

Turnover per Unit for SME in Agriculture Distributed by Industry During 2008-2014

\begin{tabular}{|c|c|c|c|c|c|c|c|c|}
\hline \multirow{2}{*}{$\begin{array}{l}\text { Nr. } \\
\text { Crt. }\end{array}$} & \multirow{2}{*}{ Sub-sectors of agriculture } & \multirow{2}{*}{$\begin{array}{l}\text { Turnover per } \\
\text { unit at } \\
\text { december 31, } \\
2014 \\
\text {-lei- }\end{array}$} & \multicolumn{6}{|c|}{ Dynamics (2008 = 100\%) } \\
\hline & & & 2009 & 2010 & 2011 & 2012 & 2013 & 2014 \\
\hline 1 & Total Romanian real economy & $2,434,541$ & 81.90 & 93.34 & 106.30 & 108.20 & 105.33 & 109.46 \\
\hline 2 & Total agriculture & $2,130,701$ & 95.34 & 99.59 & 127.98 & 136.44 & 127.80 & 137.64 \\
\hline 3 & Total agriculture (SME) & 648,325 & 105.94 & 120.83 & 155.83 & 165.76 & 158.41 & 173.03 \\
\hline 4 & Plant growing & 877,519 & 98.76 & 132.79 & 171.12 & 189.86 & 172.15 & 187.06 \\
\hline 5 & Animal breeding and veterinary care & 564,693 & 115.79 & 110.06 & 146.56 & 137.37 & 149.76 & 167.96 \\
\hline 6 & Activities in mixed farms and related services & 481,879 & 107.73 & 112.79 & 167.26 & 164.88 & 154.55 & 168.08 \\
\hline 7 & Hunting including related service activities & 236,930 & 128.25 & 178.00 & 130.05 & 97.24 & 194.43 & 133.49 \\
\hline 8 & Forestry, logging, and related services & 466,905 & 95.67 & 109.70 & 118.36 & 127.34 & 133.92 & 142.92 \\
\hline 9 & Fishing, aquaculture & 231,191 & 387.62 & 110.87 & 133.96 & 186.58 & 136.68 & 141.69 \\
\hline
\end{tabular}

Source: Calculated using data from the economic and financial situations reported by economic operators from Agriculture, Romanian Ministry of Public Finance (2008-2014). 
Table 13

Operating Income per Unit for SME in Agriculture Distributed by Industry During 2008-2014

\begin{tabular}{|c|c|c|c|c|c|c|c|c|}
\hline \multirow{2}{*}{$\begin{array}{l}\text { Nr. } \\
\text { Crt. }\end{array}$} & \multirow[b]{2}{*}{ Sub-sectors of agriculture } & \multirow{2}{*}{$\begin{array}{l}\text { Operating } \\
\text { income per } \\
\text { unit at } \\
\text { december 31, } \\
2014 \\
\text {-lei- }\end{array}$} & \multicolumn{6}{|c|}{ Dynamics $(2008=100 \%)$} \\
\hline & & & 2009 & 2010 & 2011 & 2012 & 2013 & 2014 \\
\hline 1 & Total Romanian real economy & $2,543,213$ & 80.86 & 92.46 & 105.49 & 107.32 & 104.94 & 108.44 \\
\hline 2 & Total agriculture & $2,387,153$ & 92.48 & 95.98 & 123.11 & 130.81 & 122.34 & 129.72 \\
\hline 3 & Total agriculture (SME) & 741,966 & 101.02 & 112.26 & 144.91 & 155.33 & 146.87 & 158.98 \\
\hline 4 & Plant growing & $1,018,904$ & 93.60 & 117.93 & 152.47 & 169.31 & 152.61 & 162.91 \\
\hline 5 & Animal breeding and veterinary care & 632,991 & 113.42 & 110.12 & 141.94 & 136.96 & 146.36 & 163.36 \\
\hline 6 & Activities in mixed farms and related services & 549,774 & 101.05 & 106.68 & 156.54 & 157.07 & 147.29 & 154.48 \\
\hline 7 & Hunting including related service activities & 242,868 & 139.89 & 182.80 & 148.67 & 105.32 & 193.28 & 130.12 \\
\hline 8 & Forestry, logging, and related services & 514,564 & 96.65 & 105.75 & 114.55 & 121.93 & 127.43 & 144.76 \\
\hline 9 & Fishing, aquaculture & 287,665 & 290.78 & 94.13 & 135.33 & 178.91 & 127.12 & 123.32 \\
\hline
\end{tabular}

Source: Calculated using data from the economic and financial situations reported by economic operators from Agriculture, Romanian Ministry of Public Finance (2008-2014).

Table 14

Total Income per Unit for SME in Agriculture Distributed by Industry During 2008-2014

\begin{tabular}{|c|c|c|c|c|c|c|c|c|}
\hline \multirow{2}{*}{$\begin{array}{l}\text { Nr. } \\
\text { Crt. }\end{array}$} & \multirow{2}{*}{ Sub-sectors of agriculture } & \multirow{2}{*}{$\begin{array}{l}\text { Total income } \\
\text { per unit at } \\
\text { december 31, } \\
2014 \\
\text {-lei- }\end{array}$} & \multicolumn{6}{|c|}{ Dynamics $(2008=100 \%)$} \\
\hline & & & 2009 & 2010 & 2011 & 2012 & 2013 & 2014 \\
\hline 1 & Total Romanian real economy & $2,592,276$ & 80.45 & 93.02 & 78.63 & 107.48 & 104.73 & 107.25 \\
\hline 2 & Total agriculture & 2,431,088 & 92.83 & 96.68 & 105.73 & 131.20 & 122.78 & 130.30 \\
\hline 3 & Total agriculture (SME) & 766,574 & 101.37 & 113.63 & 146.41 & 156.49 & 148.88 & 162.35 \\
\hline 4 & Plant growing & $1,063,729$ & 94.44 & 119.85 & 154.12 & 170.64 & 155.71 & 167.99 \\
\hline 5 & Animal breeding and veterinary care & 638,299 & 113.73 & 110.78 & 142.62 & 138.36 & 147.22 & 163.59 \\
\hline 6 & Activities in mixed farms and related services & 576,436 & 100.88 & 107.62 & 158.32 & 157.74 & 148.28 & 159.35 \\
\hline 7 & Hunting including related service activities & 247,800 & 141.68 & 189.04 & 158.48 & 108.84 & 201.22 & 132.32 \\
\hline 8 & Forestry, logging, and related services & 518,222 & 96.39 & 106.65 & 116.36 & 122.50 & 127.99 & 144.57 \\
\hline 9 & Fishing, aquaculture & 289,360 & 281.37 & 92.59 & 132.56 & 176.45 & 124.16 & 119.76 \\
\hline
\end{tabular}

Source: Calculated using data from the economic and financial situations reported by economic operators from Agriculture, Romanian Ministry of Public Finance (2008-2014).

Table 15

Operating Profit per Unit for SME in Agriculture Distributed by Industry During 2008-2014

\begin{tabular}{|c|c|c|c|c|c|c|c|c|}
\hline \multirow{2}{*}{$\begin{array}{l}\text { Nr. } \\
\text { Crt. }\end{array}$} & \multirow{2}{*}{ Sub-sectors of agriculture } & \multirow{2}{*}{$\begin{array}{l}\text { Operating } \\
\text { profit per unit } \\
\text { at december } \\
31,2014 \\
\text {-lei- }\end{array}$} & \multicolumn{6}{|c|}{ Dynamics $(2008=100 \%)$} \\
\hline & & & 2009 & 2010 & 2011 & 2012 & 2013 & 2014 \\
\hline 1 & Total Romanian real economy & 177,134 & 91.20 & 101.15 & 79.53 & 83.74 & 93.99 & 100.84 \\
\hline 2 & Total agriculture & 220,806 & 87.42 & 92.73 & 151.07 & 146.31 & 128.70 & 150.54 \\
\hline 3 & Total agriculture (SME) & 100,382 & 91.69 & 97.82 & 172.14 & 152.34 & 151.11 & 189.95 \\
\hline 4 & Plant growing & 153,153 & 78.58 & 105.86 & 209.19 & 180.64 & 175.28 & 205.55 \\
\hline 5 & Animal breeding and veterinary care & 48,736 & 112.18 & 75.45 & 94.97 & 100.09 & 103.79 & 138.59 \\
\hline
\end{tabular}


Table 15 continued

\begin{tabular}{|c|c|c|c|c|c|c|c|c|}
\hline \multirow{2}{*}{$\begin{array}{l}\text { Nr. } \\
\text { Crt. }\end{array}$} & \multirow{2}{*}{ Sub-sectors of agriculture } & \multirow{2}{*}{$\begin{array}{l}\text { Operating } \\
\text { profit per unit } \\
\text { at december } \\
31,2014 \\
\text {-lei- }\end{array}$} & \multicolumn{6}{|c|}{ Dynamics $(2008=100 \%)$} \\
\hline & & & 2009 & 2010 & 2011 & 2012 & 2013 & 2014 \\
\hline 6 & Activities in mixed farms and related services & 65,955 & 93.97 & 101.33 & 181.72 & 142.05 & 140.68 & 159.35 \\
\hline 7 & Hunting including related service activities & 45,654 & 74.68 & 176.41 & 90.95 & 86.98 & 86.36 & 222.45 \\
\hline 8 & Forestry, logging, and related services & 86,975 & 125.33 & 97.67 & 96.59 & 107.58 & 120.85 & 222.04 \\
\hline 9 & Fishing, aquaculture & 49,160 & 83.84 & 46.36 & 176.60 & 116.52 & 97.11 & 135.46 \\
\hline
\end{tabular}

Source: Calculated using data from the economic and financial situations reported by economic operators from Agriculture, Romanian Ministry of Public Finance (2008-2014).

Table 16

Operating Losses per Unit for SME in Agriculture Distributed by Industry During 2008-2014

\begin{tabular}{|c|c|c|c|c|c|c|c|c|}
\hline \multirow{2}{*}{$\begin{array}{l}\text { Nr. } \\
\text { Crt. }\end{array}$} & \multirow{2}{*}{ Sub-sectors of agriculture } & \multirow{2}{*}{$\begin{array}{l}\text { Operating } \\
\text { Losses per } \\
\text { unit at } \\
\text { december 31, } \\
2014 \\
\text {-lei- }\end{array}$} & \multicolumn{6}{|c|}{ Dynamics (2008 = 100\%) } \\
\hline & & & 2009 & 2010 & 2011 & 2012 & 2013 & 2014 \\
\hline 1 & Total Romanian real economy & 68,216 & 130.96 & 138.34 & 160.50 & 144.41 & 138.74 & 134.02 \\
\hline 2 & Total agriculture & 80,336 & 152.50 & 161.85 & 200.26 & 150.26 & 300.37 & 292.78 \\
\hline 3 & Total agriculture (SME) & 55,603 & 122.66 & 134.45 & 162.31 & 142.24 & 194.28 & 266.20 \\
\hline 4 & Plant growing & 90,056 & 117.07 & 109.79 & 102.71 & 117.15 & 152.63 & 311.68 \\
\hline 5 & Animal breeding and veterinary care & 43,735 & 100.14 & 177.33 & 178.38 & 192.97 & 350.64 & 249.47 \\
\hline 6 & Activities in mixed farms and related services & 28,399 & 158.53 & 131.83 & 247.38 & 142.61 & 172.87 & 173.19 \\
\hline 7 & Hunting including related service activities & 78,129 & 184.41 & 61.58 & 111.39 & 164.44 & 403.92 & 289.87 \\
\hline 8 & Forestry, logging, and related services & 17,442 & 154.53 & 201.99 & 340.90 & 178.35 & 135.98 & 147.91 \\
\hline 9 & Fishing, aquaculture & 51,360 & 80.96 & 110.47 & 132.78 & 143.71 & 226.07 & 224.81 \\
\hline
\end{tabular}

Source: Calculated using data from the economic and financial situations reported by economic operators from Agriculture, Romanian Ministry of Public Finance (2008-2014).

Table 17

Gross Profit per Unit for SME in Agriculture Distributed by Industry During 2008-2014

\begin{tabular}{|c|c|c|c|c|c|c|c|c|}
\hline \multirow{2}{*}{$\begin{array}{l}\text { Nr. } \\
\text { Crt. }\end{array}$} & \multirow[b]{2}{*}{ Sub-sectors of agriculture } & \multirow{2}{*}{$\begin{array}{l}\text { Gross profit } \\
\text { per unit at } \\
\text { december 31, } \\
2014 \\
\text {-lei- }\end{array}$} & \multicolumn{6}{|c|}{ Dynamics $(2008=100 \%)$} \\
\hline & & & 2009 & 2010 & 2011 & 2012 & 2013 & 2014 \\
\hline 1 & Total Romanian real economy & 164,720 & 94.74 & 107.08 & 82.94 & 87.63 & 102.52 & 112.37 \\
\hline 2 & Total agriculture & 199,573 & 77.21 & 100.20 & 177.38 & 168.12 & 154.74 & 188.05 \\
\hline 3 & Total agriculture (SME) & 95,179 & 77.29 & 96.00 & 180.23 & 155.27 & 158.93 & 207.97 \\
\hline 4 & Plant growing & 147,595 & 70.32 & 106.10 & 223.45 & 187.92 & 186.10 & 226.12 \\
\hline 5 & Animal breeding and veterinary care & 41,084 & 108.09 & 72.52 & 94.73 & 103.42 & 105.32 & 153.34 \\
\hline 6 & Activities in mixed farms and related services & 62,415 & 87.28 & 100.61 & 181.07 & 135.05 & 142.91 & 170.86 \\
\hline 7 & Hunting including related service activities & 44,499 & 50.13 & 188.20 & 99.45 & 89.01 & 91.84 & 235.47 \\
\hline 8 & Forestry, logging, and related services & 83,342 & 73.77 & 85.76 & 89.98 & 107.18 & 124.64 & 235.42 \\
\hline 9 & Fishing, aquaculture & 47,268 & 84.57 & 43.94 & 192.42 & 67.49 & 105.98 & 152.75 \\
\hline
\end{tabular}

Source: Calculated using data from the economic and financial situations reported by economic operators from Agriculture, Romanian Ministry of Public Finance (2008-2014). 
Table 18

Total Loss per Unit for SME in Agriculture Distributed by Industry During 2008-2014

\begin{tabular}{|c|c|c|c|c|c|c|c|c|}
\hline \multirow{2}{*}{$\begin{array}{l}\text { Nr. } \\
\text { Crt. }\end{array}$} & \multirow{2}{*}{ Sub-sectors of agriculture } & \multirow{2}{*}{$\begin{array}{l}\text { Total loss per } \\
\text { unit at } \\
\text { december 31, } \\
2014 \\
\text {-lei- }\end{array}$} & \multicolumn{6}{|c|}{ Dynamics $(2008=100 \%)$} \\
\hline & & & 2009 & 2010 & 2011 & 2012 & 2013 & 2014 \\
\hline 1 & Total Romanian real economy & 85,231 & 112.02 & 113.13 & 124.24 & 119.08 & 106.29 & 107.42 \\
\hline 2 & Total agriculture & 94,130 & 111.30 & 104.47 & 128.62 & 101.93 & 177.92 & 181.00 \\
\hline 3 & Total agriculture (SME) & 59,913 & 118.77 & 111.12 & 144.52 & 124.76 & 154.75 & 205.40 \\
\hline 4 & Plant growing & 96,452 & 108.60 & 86.40 & 81.66 & 99.22 & 117.44 & 226.34 \\
\hline 5 & Animal breeding and veterinary care & 47,760 & 102.96 & 146.13 & 149.28 & 162.75 & 269.83 & 196.60 \\
\hline 6 & Activities in mixed farms and related services & 30,724 & 138.24 & 108.11 & 257.08 & 114.85 & 129.28 & 127.45 \\
\hline 7 & Hunting including related service activities & 89,623 & 240.96 & 64.18 & 119.04 & 198.25 & 466.91 & 332.59 \\
\hline 8 & Forestry, logging, and related services & 19,196 & 189.58 & 212.79 & 365.34 & 216.19 & 152.96 & 150.03 \\
\hline 9 & Fishing, aquaculture & 55,060 & 96.07 & 109.17 & 147.44 & 163.60 & 243.88 & 240.57 \\
\hline
\end{tabular}

Source: Calculated using data from the economic and financial situations reported by economic operators from Agriculture, Romanian Ministry of Public Finance (2008-2014).

Table 19

Total Debts per Unit for SME in Agriculture Distributed by Industry During 2008-2014

\begin{tabular}{|c|c|c|c|c|c|c|c|c|}
\hline \multirow{2}{*}{$\begin{array}{l}\text { Nr. } \\
\text { Crt. }\end{array}$} & \multirow{2}{*}{ Sub-sectors of agriculture } & \multirow{2}{*}{$\begin{array}{l}\text { Total debts per } \\
\text { unit at } \\
\text { december 31, } \\
2014 \\
\text {-lei- }\end{array}$} & \multicolumn{6}{|c|}{ Dynamics $(2008=100 \%)$} \\
\hline & & & 2009 & 2010 & 2011 & 2012 & 2013 & 2014 \\
\hline 1 & Total Romanian real economy & $1,609,499$ & 89.19 & 102.55 & 116.35 & 118.21 & 114.56 & 113.68 \\
\hline 2 & Total agriculture & $2,065,682$ & 105.55 & 113.02 & 128.45 & 138.85 & 136.64 & 147.92 \\
\hline 3 & Total agriculture (SME) & 970,320 & 117.13 & 130.24 & 150.03 & 160.70 & 162.84 & 185.00 \\
\hline 4 & Plant growing & $1,399,443$ & 112.08 & 122.87 & 136.35 & 150.54 & 154.66 & 184.66 \\
\hline 5 & Animal breeding and veterinary care & 795,295 & 109.31 & 121.99 & 145.11 & 166.06 & 179.96 & 189.84 \\
\hline 6 & Activities in mixed farms and related services & 683,970 & 126.74 & 137.99 & 175.45 & 167.33 & 166.25 & 163.04 \\
\hline 7 & Hunting including related service activities & $1,144,759$ & 205.38 & 126.63 & 158.79 & 222.69 & 222.35 & 368.75 \\
\hline 8 & Forestry, logging, and related services & 494,404 & 154.03 & 163.34 & 197.28 & 182.71 & 157.09 & 184.94 \\
\hline 9 & Fishing, aquaculture & 824,306 & 88.81 & 169.89 & 148.17 & 179.38 & 164.04 & 174.08 \\
\hline
\end{tabular}

Source: Calculated using data from the economic and financial situations reported by economic operators from Agriculture, Romanian Ministry of Public Finance (2008-2014).

\section{Conclusion}

Rural areas, as reported by the EU Rural Review, are estimated to generate $48 \%$ of the gross value of the EU economy and 56\% of total employment in the Member States. The future is for the rural economy SMEs, many of which are micro-enterprises with a high percentage of self-employment jobs (Rippey, 2009). As in all fields, the agriculture policies give decisive significance fair allocation of investment to agricultural production and productivity. Supporting these policies give new models of microfinance adapted to the current environment of structuring the farm to the needs of small farmers; given that at present Romania has over 2,500,000 small farms semi-subsistence (Ministry of Agriculture and Rural Development 2014-2020, 2014), contributing directly and indirectly to sustainable development of the Romanian village. After a period of searching and waiting, Romania is obliged to approach the decisions that lead to the restoration of new principles and creat new institutions to 
provide loans for actors and local sectors vital to the economic consolidation of settlements and human welfare. It's about creating specialized microfinance institutions to finance economic entities with legal personality; non-banking financial institutions in rural areas to support crediting legal entities and individuals active: institutions that conduct microfinance institution specialized education in rural areas (Madgearu Virgil, 1914). The capital required to establish such institutions should be ensured through government financial contributions for the payment to be repaid in time. Another very important aspect is to create innovative models of microfinance and continuous training of human capital involved in providing financial services in rural areas and in the financial education of those accessing microcredit (Borzaga, 2013). To achieve this goal of establishing a rural microfinance innovative and coherent, it would be desirable to start with what was good in areas of the credit system in Romania in the interwar period, especially the innovative models today existing in some EU countries and creating own innovative models of microcredit.

\section{What to Do Next?}

Creation of a mechanism is to help stimulate the creation of a value-added manufacturing chain more higher, so turnover is to ensure both current manufacturing costs and pay old debts.

The funding mechanism structure is adapted to the specific needs of SME's financing in agriculture (seasonal production, risk of natural disasters and other unforeseen events, minimum guarantees, etc.).

\section{References}

Borzaga, C. (2013). Unlocking the potential of social economy and social enterprises. EURICSE.

Chitea, L. (2013). Opportunities and constraints for rural communities. Romanian Publishing Agricultural capital, Bucharest. Herman, E., \& Stefanescu, D. (2009a). Impact of lending in agriculture lending process. PIM Publishing House, Iasi.

Herman, E., \& Stefanescu, D. (2009b). An analysis of domestic credit granted for types of institutional sectors. PIM Publishing House, Iasi.

Madgearu Virgil, N. (1914). Structure and trends popular banks in Romania. Romanian Printing House, Bucharest.

Ministry of Agriculture and Rural Development 2014-2020. (2014). National plan for rural development. Bucharest. Retrieved from www.madr.ro

Rippey, P. (2009). Microfinance and climate change: Threats and opportunities. CGAP.

Romanian Ministry of Public Finance. (2008-2014). Balance sheet for the SMEs in Romania 2008-2014.

Sen, A. (1999). Development as freedom. Oxford University Press. 